\title{
Increased Serum Concentration of IgA2 Subclass and IgA2/IgA1 Ratio: Specific Markers of Chronic Alcoholic Abuse?
}

\author{
Dominique Meillet ${ }^{1}$, Françoise Labrousse ${ }^{2}$, Marie Odile Benoit ${ }^{3}$, Alain Hernvann ${ }^{4}$, Lucile Musset $^{5}$ and \\ Geneviève van Amerongen ${ }^{6}$ \\ 1 Biochimie, Hôpital de la Salpêtrière, Paris, France \\ 2 Biochimie, Hôpital Laennec, Paris, France \\ ${ }^{3}$ Biochimie, Hôpital Broussais, Paris, France \\ ${ }^{4}$ Biochimie, Hôpital Cochin, Paris, France \\ 5 Immunochimie, Hôpital de la Salpêtière, Paris, France \\ ${ }^{6}$ Biochimie, Hôpital Raymond-Poincaré, Garches, France \\ 1-6 Groupe d'Evaluation et de Recherche des Biologistes de l'Assistance Publique des Hôpitaux de Paris (GERBAP)
}

Summary: Enhanced serum IgA concentrations are common in alcoholic liver cirrhosis, but functional differences between IgA subclasses and their relation with interleukin-6 (IL-6) have not been described. Distinct immunoregulatory mechanisms may exist that selectively affect one subclass. This possibility prompted us to investigate the distribution of IgA1 and IgA2 subclasses in the serum of 25 heavy alcohol drinkers (alcohol: 80 to $200 \mathrm{~g}$ per day) without clinical disorders, in comparison with 35 patients affected by alcoholic liver cirrhosis, 29 viral hepatitis patients and 33 social drinkers as a control group. Mean ( $\pm \mathrm{SD})$ IgA2 concentration $(0.56 \pm 0.31 \mathrm{~g} / \mathrm{l})$ was significantly increased $(p<0.01)$ in heavy alcohol drinkers, with an $\operatorname{IgA} 2 / \operatorname{IgAl}$ ratio of $0.33 \pm 0.12$, while the mean total IgA concentration was similar to the control group. Mean IgA1 and IgA2 concentrations were significantly increased $(p<0.001)$ in alcoholic liver cirrhosis patients $(6.13 \pm 4.52 \mathrm{~g} / 1$ and $1.83 \pm 1.93 \mathrm{~g} / 1$ respectively, with an $\operatorname{IgA} 2 / \operatorname{IgA} 1$ ratio of $0.32 \pm 0.19)$ and viral hepatitis patients $(3.66 \pm 2.59 \mathrm{~g} / 1$ and $0.69 \pm 0.67 \mathrm{~g} / \mathrm{l}$ respectively, with an IgA2/IgA1 ratio of $0.21 \pm 0.14)$ High serum IL- 6 concentrations $(34 \pm 33 \mathrm{ng} / \mathrm{l})$ were correlated with elevated IgA1 and IgA2 concentrations only in patients with alcoholic liver cirrhosis. IgA2 subclass and IgA2/IgA1 ratio could therefore be used as markers of chronic alcohol abuse directly related to the extent and duration of the alcohol abuse and the effectiveness of alcohol withdrawal.

\section{Introduction}

Abnormalities in the immune systems of alcoholic liver cirrhosis patients have been described (1-4). However, their pathogenic significance and clinical implications remain unknown. Hypergammaglobulinaemia, mainly enhancement of the serum IgA concentration, is a common immunological finding in patients with alcoholic liver cirrhosis $(5-7)$. It has been demonstrated that this high immunoglobulin concentration is not due to abnormal catabolism of IgA (1-2).

Swerdlow et al. have shown in patients with alcoholic liver disease that the IgA2 subclass forms a major subclass component contributing to the continuous pattern of IgA deposition in hepatic tissues (8).

Recently, high serum IgA2 concentrations were found in heavy alcohol drinkers without alcoholic liver cirrhosis (9). This subclass may be a predictive marker for evolution to alcoholic liver disease.

In addition, increased serum concentrations and in vitro spontaneous or induced production of interleukin-6 (IL-
6) peripheral blood monoclonal cells have been reported in patients with alcoholic liver cirrhosis (10). IL-6 production correlates closely with IgA serum levels. This abnormality may be related to overproduction of IgA and immune disturbances in patients with alcoholic liver disease.

We have studied serum IgA, IgA1, IgA2 and IL-6 concentrations in heavy alcohol drinkers without clinical liver disease in comparison with alcoholic liver cirrhosis and viral hepatitis patients to clarify the significance of the high serum IgA2 concentration in relation to alcohol consumption.

\section{Patients and Methods}

Patients

The biochemical hepatic characteristics of the four groups are given in table 1.

- The control group comprised thirty-three healthy subjects $(12$ women and 21 men, mean age \pm SD: $42 \pm 12$ years, range: $24-$ 56 years) who were social drinkers (alcohol ingestion $<40 \mathrm{~g}$ per day) with normal hepatic characteristics. 
Tab. 1 Hepatic characteristics (mean \pm SD (median)) of the studied population.

\begin{tabular}{lcccc}
\hline Group & $\mathrm{n}$ & $\begin{array}{c}\text { Alanine amino- } \\
\text { transferase (U/l) }\end{array}$ & $\begin{array}{c}\text { Aspartate amino- } \\
\text { transferase (U/1) }\end{array}$ & $\begin{array}{l}\gamma \text {-Glutamyl- } \\
\text { transferase (U/1) }\end{array}$ \\
\hline Reference values $\left(30^{\circ} \mathrm{C}\right)$ & & $4-45$ & $10-45$ & $5-40$ \\
Control social drinkers & 33 & $17 \pm 16(15)$ & $18 \pm 15(13)$ & $21 \pm 20(18)$ \\
Heavy alcohol drinkers & 25 & $25 \pm 5(23)$ & $20 \pm 5(21)$ & $55^{* *} \pm 8(54)$ \\
Alcoholic cirrhosis & 35 & $67^{*} \pm 80(55)$ & $157^{* *} \pm 75(139)$ & $534^{* *} \pm 523(248)$ \\
Viral hepatitis & 29 & $106^{* *} \pm 57(111)$ & $85^{*} \pm 69(75)$ & $71^{* *} \pm 28(70)$ \\
\hline
\end{tabular}

${ }^{*} \mathrm{p}<0.01 ; * * \mathrm{p}<0.001$ vs control social drinkers (U-test of Mann \& Whitney).

- Twenty-five heavy alcohol drinkers (10 women and 15 men, mean age \pm SD: $52 \pm 10$ years, range: $35-70$ years) who had ingested more than $80 \mathrm{~g}$ alcohol daily for at least five consecutive years without clinical or biological signs of liver disease were volunteers for a course of alcohol withdrawal.

- Thirty-five patients ( 7 woman and 28 men, mean age \pm SD: 48 \pm 11 years, range: $31-74$ years) with alcoholic liver cirrhosis were grouped according to the Child-Pugh classification (11). They were studied at least two months after cessation of alcohol intake. In all cases, cirrhosis was due to chronic alcohol ingestion and confirmed by histology. None of the patients had overt signs of viral hepatic infection.

- Twenty-nine patients ( 12 women and 17 men, mean age \pm SD: $50 \pm 15$ years, range: $17-71$ years) with viral hepatitis $B$ $(n=13), C(n=11)$ and non-A, non-B, non-C $(n=5)$ were controlled in this study. The hepatitis was diagnosed according to conventional criteria, including serological markers using currently available assays and liver biochemical test abnormalities (alanine amino-transferase $>1.5$ the upper normal limit for longer than six months). None of the viral hepatitis patients had liver cirrhosis.

In alcoholic liver cirrhosis and viral hepatitis patients, alcohol ingestion was less than $40 \mathrm{~g}$ per day at the time of the sample.

All patients gave their informed consent to the experimental protocol.

\section{Serum samples}

Blood samples were collected in sterile, clean, dry tubes and rapidly separated after coagulation. Serum was stored at $-20^{\circ} \mathrm{C}$.

\section{Measurement of serum IgA, IgA1 and IgA2 concentrations}

Concentrations of $\operatorname{IgA}$, and $\operatorname{IgA} 1, \operatorname{IgA} 2$ subclasses in serum were measured by a sandwich time-resolved immunofluorometric assay as previously described $(12-14)$. The plates for microtitration (Microwell-Maxisorp $^{\mathrm{TM}}$, Nunc, Roskilde, Denmark) were coated overnight at $4{ }^{\circ} \mathrm{C}$ with $200 \mu \mathrm{l}$ of polyclonal anti-human $\alpha$-chain (Dako, Glostrup, Denmark), at $0.005 \mathrm{~g} / 1$ for IgA and IgA1, and at $0.010 \mathrm{~g} / 1$ for IgA2, diluted in $0.05 \mathrm{~mol} / 1 \mathrm{~K}_{2} \mathrm{HPO}_{4}$ buffer adjusted to $\mathrm{pH}$ 8.5. Excess binding sites were blocked by three washes with $0.05 \mathrm{~mol} / 1 \mathrm{NaH}_{2} \mathrm{PO}_{4}$ di-hydrate containing $5 \mathrm{~g} / \mathrm{l}$ bovine serum albu$\mathrm{min}$ and $60 \mathrm{~g} / 1$ sorbitol. Six serial dilutions of the OSAU standard (Behring, Marburg, Germany; IgA $=2.45 \mathrm{~g} / 1, \mathrm{IgA} 1=2.02 \mathrm{~g} / \mathrm{l}$ and IgA2 $=0.43 \mathrm{~g} / 1$ ) and two dilutions of the tested samples, in 0.1 $\mathrm{mol} / 1 \mathrm{Tris}-\mathrm{HCl}$ buffer adjusted to $\mathrm{pH} 7.75$ (added to $0.15 \mathrm{~mol} / \mathrm{l}$ $\mathrm{NaCl}, 5 \mathrm{~g} / \mathrm{l}$ bovine serum albumin, $1 \mathrm{~g} / \mathrm{l}$ Tween 20 and $0.02 \mathrm{~mol} / \mathrm{l}$ di-ethylene-triamino pentacetic acid), were applied in duplicate and incubated for 2 hours at $20^{\circ} \mathrm{C}$ with continuous shaking. After three washes with $0.05 \mathrm{~mol} / 1$ Tris- $\mathrm{HCl}$ buffer at $\mathrm{pH} 7.75$ containing 0.25 $\mathrm{g} / 1$ Tween $20,200 \mu \mathrm{l}$ of the following europium-labelled antibodies $(0.00025 \mathrm{~g} / 1)$ were added for 1 hour at $2^{\circ} \mathrm{C}$ with gentle shaking: anti-human $\alpha$-chain (Dako), monoclonal IgG1K to human $\alpha 1$-chain (clone NI 69-11, Nordimmune ${ }^{\mathrm{TM}}$, Nordic, The Netherlands) and monoclonal IgGlK to human $\alpha_{2}$-chain (clone NI J 12, Nordimmu$\mathrm{ne}^{\mathrm{TM}}$, Nordic). Two hundred $\mu \mathrm{l}$ of the enhancement solution (Wallac, Turku, Finland) were then added for 10 minutes with con- tinuous shaking to dissociate the europium ions from the labelled immune complexes, providing highly fluorescent chelates (15). The fluorescence level was measured after a rest period of $10 \mathrm{~min}-$ utes, using a fluorometer with a xenon flash lamp (1230 Arcus ${ }^{\mathrm{TM}}$ Fluorometer, Wallac). The concentrations of IgA, IgA1 and IgA2 were calculated by the standard curves.

The reliability of the reagents used in this assay had been previously verified (specificity $99 \%$ for anti-IgA1 and $98 \%$ for antiIgA2; sensitivity $1 \mu \mathrm{g} / 1$ for both subclasses; linearity $10-1000 \mu \mathrm{g} / 1$ for IgA1 and $10-400 \mu \mathrm{g} / 1$ for IgA2; intra-assay variations $4.7-$ $6.1 \%$; inter-assay variations $6.7-9.1 \%)(12)$.

\section{Measurement of serum interleukin- 6 concentration}

Level of IL-6 in serum was measured by means of an enzyme amplified sensitivity immunoassay, performed on a microtitration plate (Medgenix, Fleurus, Belgium). It is based on the oligoclonal system in which several monoclonal antibodies directed against distinct epitopes of IL- 6 are used. The assay was performed directly on serum without any treatment or extraction. The amount of substrate (tetramethylbenzidine- $\mathrm{H}_{2} \mathrm{O}_{2}$ ) turnover was determined colorimetrically by measuring absorbance at $450 \mathrm{~mm}$.

\section{Statistical analysis}

Results were expressed as arithmetic mean \pm standard deviation (SD) and median. For the different properties, results were expressed as frequency (\%) in comparison with the normal upper limit (mean \pm 2 SD) of each property obtained for the control social drinkers. The Mann \& Whitney U-test was used to compare the data from each group versus the control group. For correlation studies, Spearman's rank correlation was used. Values of $p \leq 0.05$ were taken as significant.

\section{Results}

The results of the measurement of $\operatorname{IgA}, \operatorname{IgA} 1$ and $\operatorname{IgA} 2$ subclasses and IL-6 concentrations are expressed in table 2 and $\operatorname{IgA} 2 / \operatorname{IgA} 1$ ratios in figure 1.

\section{Serum $\operatorname{IgA}, \operatorname{IgA} 1$ and $\operatorname{IgA} 2$ concentrations and $\operatorname{Ig} A 2 / \operatorname{IgA} 1$ ratio}

In this study, there was no difference in IgA subclass concentrations and $\operatorname{IgA} 2 / \operatorname{IgA} 1$ ratios between men and women in the heavy alcohol drinkers and alcohol liver cirrhosis patients, even though women are far more prone to alcohol-induced liver damage.

- In the heavy alcohol drinkers, the IgA concentration was elevated in $3 / 25(12 \%)$ of patients; the prevalence of elevated concentrations of IgA1, 1/25 (4\%) and IgA2, $7 / 25 \quad(28 \%)$ differed significantly 
Tab. 2 Serum concentration (mean \pm SD (median)) of the $\operatorname{IgA}, \operatorname{IgAl}, \operatorname{IgA1}$ and interleukin-6.

\begin{tabular}{lcrrrr}
\hline Group & $\mathrm{n}$ & \multicolumn{1}{c}{$\operatorname{IgA}(\mathrm{g} / \mathrm{l})$} & \multicolumn{1}{c}{$\operatorname{IgA1}(\mathrm{g} / \mathrm{l})$} & \multicolumn{1}{c}{$\operatorname{IgA2}(\mathrm{g} / \mathrm{l})$} & $\mathrm{IL}-6(\mathrm{ng} / \mathrm{l})$ \\
\hline Control social drinkers & 33 & $2.42 \pm 0.86(2.31)$ & $2.18 \pm 0.73(2.27)$ & $0.39 \pm 0.34(0.28)$ & $3.8 \pm 1.9(3)$ \\
Heavy alcohol drinkers & 25 & $2.30 \pm 1.30(2.12)$ & $1.77^{*} \pm 1.03(1.56)$ & $0.56^{* *} \pm 0.31(0.55)$ & $4 \pm 1.9(3)$ \\
Alcoholic cirrhosis & 35 & $7.61^{* *} \pm 5.29(7.01)$ & $6.13^{* *} \pm 4.52(4.34)$ & $1.83^{* * *} \pm 1.93(1.20)$ & $34^{* * *} \pm 33(22)$ \\
Viral hepatitis & 29 & $4.45^{* *} \pm 3.03(3.47)$ & $3.66^{*} \pm 2.59(2.60)$ & $0.69^{*} \pm 0.67(0.45)$ & $150^{*} \pm 322(12)$ \\
\hline
\end{tabular}

$* \mathrm{p}<0.05 ; * * \mathrm{p}<0.01 ; * * \mathrm{p}<0.001$ vs control social drinkers (U-test of Mann \& Whitney).

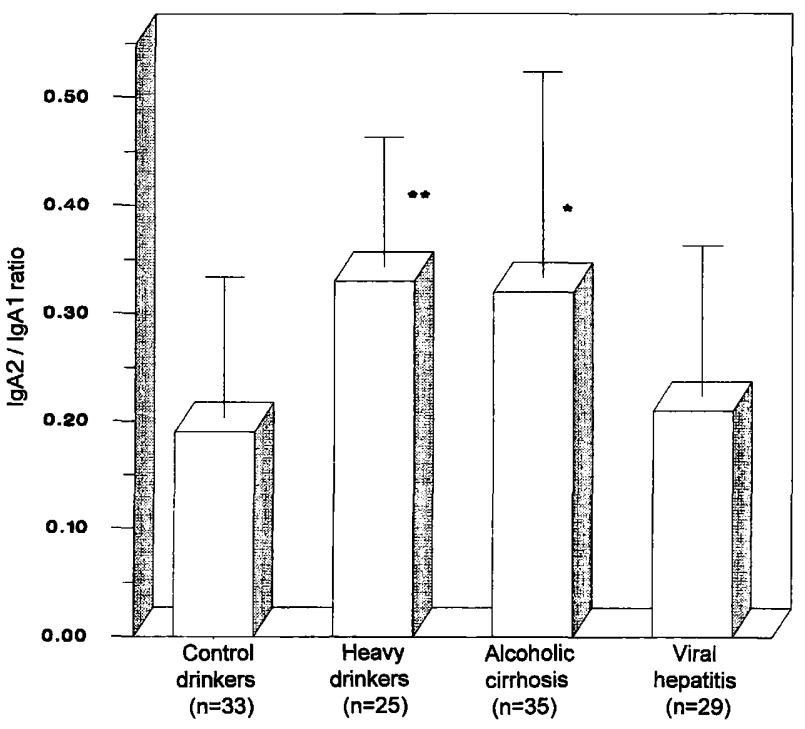

Fig. 1 IgA2/IgA1 ratio (mean \pm SD) in control drinkers, in heavy drinkers, and in patients with liver disease.

* $\mathrm{p}<0.01 ; * * \mathrm{p}<0.001$ vs control drinkers (U-test of Mann \& Whitney).

$(\mathrm{p}<0.01)$, with a predominance of $\operatorname{IgA} 2$. The $\operatorname{IgA} 2 /$ IgAl ratio was elevated in $8 / 25$ of patients $(32 \%)$.

- In alcohol liver cirrhosis patients, the IgA concentration was elevated in $22 / 35$ patients $(63 \%)$; the prevalence of the elevated concentrations did not differ between IgA1, 20/35 (57\%) and IgA2 22/35 (63\%). The IgA2/IgA1 ratio was elevated in $9 / 35$ patients (26\%).

- In viral hepatitis patients, the IgA concentration was elevated in $12 / 29$ patients (41\%), the prevalence of elevated concentrations of IgA1, 11/29 (38\%) and IgA2 5/29 (17\%) differed significantly $(\mathrm{p}<0.01)$, with a predominance of IgA1. The IgA2/IgA1 ratio was elevated in $3 / 29$ patients $(10 \%)$.

\section{Serum concentration of interleukin- 6}

Mean IL-6 concentration was significantly increased in patients with alcohol liver cirrhosis $(p<0.001)$ and in viral hepatitis patients $(p<0.05)$. In this last group, there was a wide range of values $(3-1230 \mathrm{ng} / \mathrm{l})$. In these two groups, the prevalence of elevated concentrations of IL-6 was 10/17 (59\%) and 12/23 (52\%) respectively, and did not significantly differ.
Correlations between serum IgA, IgA 1 and IgA2, and interleukin- 6 concentrations

In the heavy alcohol drinkers, IgA1 and IgA2 concentrations were positively correlated $(p<0.01)$. In contrast, in alcohol liver cirrhosis and viral hepatitis patients, the elevated IgA1 and IgA2 serum concentrations were inversely correlated. In patients with alcoholic liver cirrhosis, a significant positive correlation $(\mathrm{p}<0.01)$ was observed between elevated IgA1 and IgA2 concentrations and IL- 6 secretion.

\section{Discussion}

The reliability criteria for the time-resolved immunofluorometric assay used for the measurement of total IgA and $\operatorname{IgA} 1$, and $\operatorname{IgA} 2$ subclasses were very satisfactory. This non-isotopic method is simple to perform and its high sensitivity makes it suitable for the determination of serum IgA1 and IgA2 concentrations in patients with alcoholic liver disease.

\section{Heavy alcohol drinkers and alcoholic cirrhosis patients}

In the heavy alcohol drinkers and the alcoholic liver cirrhosis patients, in whom the alcohol factor was present, the study showed an increased IgA2/IgA1 ratio. Whatever the total IgA concentration, the ratios in the heavy drinkers and alcoholic cirrhosis patients $(0.33 \pm 0.12$ and $0.32 \pm 0.19$, respectively) were significantly different from the control social drinkers and the viral hepatitis patients. This agrees with our previous studies in which serum IgA subclass distributions were anlyzed in alcohol liver disease (9). The increase in IgA2/IgA1 ratio could constitute a diagnostic or predictive marker in heavy alcohol drinkers (prevalence: $32 \%$ ) evolving to cirrhosis $(26 \%)$, while this prevalence in viral hepatitis patients is $10 \%$. In heavy alcoholic drinkers without clinical liver disease, microvascular changes in the intestinal tract may be considered as the cause of the plasma protein loss into the jejunal lumen demonstrated by Buell \& Beck, and Ray et al. in the dog $(16,17)$. Several studies have shown the direct toxic effects of alcohol on intestinal epithelial cells and hepatocytes $(18$, 19). In particular, loss of superficial cells and damage to the upper layer of mucosa can be observed in the intesti- 
nal epithelium (20). These morphological changes in the small bowel epithelium are found even in the absence of cirrhosis (21). Alcohol increases intestinal permeability to macromolecules whatever the degree of hepatic dysfunction (22). The primary effect of alcohol may be the release of pro-inflammatory mediators such as tumour necrosis factor- $\alpha$ and IL- 6 that can increase intestinal permeability and local immunoglobulin secretion. Seillès et al. observed too that serum secretory IgA and free secretory component concentrations were significantly increased in patients with chronic alcoholic liver disease, even at a very early stage of the disease, and decreased after alcohol withdrawal (23).

\section{Alcoholic liver cirrhosis patients}

In alcoholic liver cirrhosis patients, the observation of an increase in both serum $\operatorname{IgA} 1$ and $\operatorname{IgA} 2$ concentrations with frequencies of $57 \%$ and $67 \%$ respectively, as well as the positive correlation with IL-6 concentration, seems to be a major abnormality due to an immune response against many intestinal antigens and cytokine production. IL-6 is responsible for subsequent activation of B cells, resulting in their differentiation into IgA-secreting plasma cells.

The marked increase in total serum IgA concentrations in patients with cirrhosis could be due to a secondary effect of the initial release of free secretory component/ secretory IgA to the plasma compartment, leading to abnormalities in cytokine regulation (24-26). In addition, the abnormal permeability of the intestinal barrier in alcoholic liver cirrhosis patients could allow an increased antigenic load in the plasma as food antigens and lipopolysaccharide (27). Increased IgA synthesis may reflect this increased antigenic load and the diminished T-cell suppression, or T-cell independent B-cell stimulation $(8$, 28). The IgA2 antibodies also have lipopolysaccharide and other amphiphilic components of Gram-negative bacteria as targets (29-30). Moreover, peripheral blood mononuclear cells from patients with alcoholic liver cirrhosis show an increased lipopolysaccharide-induced IL-6 secretion, which has been correlated with increased IgA serum concentrations $(10,26)$.

Recently, Guillemin et al. have shown that IgA faecal output was increased in alcoholic liver cirrhosis patients in comparison with control social drinkers (31). This observation confirms the possible role of the gut-associated lymphoid tissue in the serum IgA subclass metabolism.
Intestinal IgA synthesis may be stimulated in alcohol liver cirrhosis patients and could help explain the serum IgA2 subclass origin also. This IgA2 subclass formed the major subclass contributing to the continuous pattern of IgA deposition in hepatic tissues (8). The role of this subclass seems very important in the extent of the liver damage and its serum increase may be related to alcohol consumption.

\section{Viral hepatitis patients}

In viral hepatitis patients, while there is an increase in serum IgA2 subclass, the absence of any difference in the IgA2/IgA1 ratio from the control social drinkers suggests that the IgA metabolism is different in heavy alcohol drinkers and alcoholic liver cirrhosis patients. The pro-inflammatory cytokines (IL-6) induce IgA secretion in both subclasses. The lower significance of the serum IL-6 increase in viral hepatitis patients than in alcoholic liver cirrhosis patients may be explained by the marked heterogeneity of this group (nature of the virus, severity of the infection). In fact, in viral hepatitis patients, there are probably only slight disturbances in the intestinal permeability, but the IgA metabolism seems to be profoundly disturbed.

\section{Conclusion}

The measurement of serum IgA sbuclasses and IgA2/ IgAl ratio in patients with either normal or elevated serum total IgA could provide a means to detect alcoholic liver patients that are heavy alcoholic drinkers or viral hepatitis patients evolving to clinical complications such as cirrhosis or damage to the gastro-intestinal tract. In these situations, the IgA2 subclass, and the IgA2/IgA1 ratio in particular, could be specific markers of chronic alcohol abuse directly related to the extent and duration of the alcohol abuse. However, further studies are required to confirm this, including a longitudinal study in heavy drinkers evolving to cirrhosis.

\section{Acknowledgements}

This study was performed with G.E. R. B. A.P. (Groupe d'Evaluation et de Recherche des Biologistes de l'Assistance Publique des Hôpitaux de Paris, France).

We thank $\operatorname{Dr} O$. Gaillard, Prof. F. Lunel and Prof. E. Seillès for their contribution to this study, and C. Hapiot for preparation of the manuscript.

\section{References}

1. Kutteh WH, Prince SJ, Phillips JO, Spenny JG, Mestecki J. Properties of immunoglobulin A in serum of individuals with liver disease and in hepatic bile. Gastroenterology 1982; 82:184-93.

2. Delacroic DL, Vaerman JP. Function of the human liver in IgA homeostasis, in plasma IgA. Ann NY Acad Sci 1983; 409:383-401. 
3. Mc Keever U, O'Mahony C, Whelan CA, Weir DG, Feighery C. Helper and suppressor $\mathrm{T}$ lymphocyte function in severe alcoholic liver disease. Clin Exp Immunol 1985; 60:39-48.

4. Nouri-Aria KT, Alexander GJM, Portmann BC, Hegarty JE, Eddleston ALWF, Williams RT. B cell function in alcoholic liver disease. J Hepatol 1986; 2:195-207.

5. Berger SR, Helms RA, Bull DM. Cirrhotic hypergammaglobulinemia: increased rates of immunoglobulin synthesis by circulating lymphoid cells. Dig Dis Sci 1979; 24:741-5.

6. Morgan MY, Ross MGR, Ng CM, Adams DM, Thomas HC, Sherlock S. HLA-B8, immunoglobulins and antibody responses in alcohol-related liver disease. J Clin Pathol 1980; 33:488-92.

7. Van de Wiel A, van Hattum J, Schuurman HJ, Kater L. Immunoglobulin A in the diagnosis of alcoholic liver disease. Gastroenterology 1988; 94:457-62.

8. Swerdlow MA, Chowdhury LN. IgA subclasses in liver tissues in alcoholic liver disease. Am J Clin Pathol 1983; 80:238-9.

9. Meillet D, Labrousse F, Benoit MO, van Amerongen G, Musset L, Hernvann A. Serum IgA subclasses and interleukin-6 in alcoholic liver disease. In: Proceedings of the 8th International Colloquium of Pont-à-Mousson - Eurobiology 1992 Sep 14-18; John Libbey Eurotext: Paris, 1993; 393-6.

10. Devière J, Content J, Denys $\mathrm{C}$, van den Bussche L, Schandene L, Wybran $J$, et al. High interleukin-6 serum levels and increased production by leucocytes in alcoholic liver cirrhosis. Correlation with IgA serum levels and lymphokines production. Clin Exp Immunol 1989; 77:221-5.

11. Pugh RNH, Murray-Lyon IM, Dawson JL, Pietroni MC, Williams N. Transection of the oesophagus for bleeding oesophageal varices. Br J Surg 1973; 60:646-9.

12. Meillet D, Gaillard O, Kapel N, Celton N, Magne D, Kapel N, et al. A new method for measurement of IgA subclasses: timeresolved immunofluorometric assay [abstract]. Ann Biol Clin 1993; 51:402.

13. Kapel N, Meillet D, Buraud M, Favennec L, Magne D, Gobert JG. Determination of anti-Cryptosporidium coproantibodies by time-resolved immunofluorometric assay. Trans RS Med Hyg 1993; 87:330-2.

14. Bélec L, Meillet D, Gaillard O, Prazuck T, Michel E, Ngondi Ekome J, et al. Decreased cervicovaginal production of both IgA1 and IgA2 subclasses in women with AIDS. Clin Exp Immunol 1995; 101:100-6.

15. Hemmila I, Dakubu S, Mukkula VM, Sitari H, Loven T. Europium as a label in time-resolved immunofluorometric assay. Ann Biochem 1984; 137:335-43.

16. Buell MG, Beck IT. Ethanol-induced mucosal microvascular stasis and enhanced plasma protein loss in the dog jejunum. Gastroenterology 1984; 86:413-20.

17. Ray M, Kinda PK, Beck IT. Mechanism of ethanol-induced jejunal microvascular and morphologic changes in the dog. Gastroenterology 1989; 96:345-54.

18. Draper LR, Gyure LA, Hall JG, Robertson D. Effect of alcohol on the integrity of the intestinal epithelium. Gut 1983; 24:399-404.
19. Lieber CS. Hepatic, metabolic and toxic effects of ethanol: 1991 update. Alcohol Clin Exp Res 1991; 15:573-92.

20. Foschi D, Marazzi M, Toti GL, Radaelli E, Ferrante F, Vaiani G, et al. Prostaglandin-stimulated recovery of the human duodenal epithelium: effects of misoprostol on ethanol damage. Am J Gastroenterol 1990; 85:1498-502.

21. Boron-Kaczmarzka A, Hryniewicz A, Kemona A, SokolewiczBobrowska $\mathrm{E}$, Miegoc $\mathrm{H}$. Morphological changes of small intestine epithelium in the course of post-alcoholic liver cirrhosis. Drug and Alcohol Dependence 1990; 25:299-303.

22. Worthington BS, Meresol L, Syrotuck JA. Effect of daily ethanol ingestion on intestinal permeability to macromolecules. Am J Dig Dis 1978; 23:23-32.

23. Seillès E, Rossel M, Vuitton DA, Mercier M, Njoya O, Capron JP, et al. Serum secretory IgA and secretory component in patients with non-cirrhotic alcoholic liver diseases. J Hepatol 1995; 22:278-85.

24. Vuitton DA, Seillès E, Cozon G, Rossel M, Bresson-Hadni $\mathrm{S}$, Revillard JP. Secretory immunoglobulin A in hepatobiliary diseases. Dig Dis Sci 1991; 9:78-91.

25. Defrance T, Vanderbielt B, Briere F, Durand I, Bousset F, Banchereau J. Interleukin-10 and transforming growth factor$\beta$ cooperate to induce anti-CD40-activated naive human B cells to secrete immunoglobulin A. J Exp Med 1992; 175:671-82.

26. Devière J, Content J, Denys $\mathrm{C}$, van den Bussche $\mathrm{P}$, Lemoine $\mathrm{O}$, Schandene $\mathrm{L}$, et al. Immunoglobulin A an interleukin-6 form a positive secretory feedback loop: a study of normal subjects and alcoholic cirrhotics. Gastroenterology 1992; 103:1296301.

27. Florent C, Levy VG, Bernier JJ. Perte de protéines intestinales et cirrhose alcoholique. Etude par la mesure de la clairance fécale de l'alpha-1-anti-trypsine. Gastroenterol Clin Biol 1982; 6:68-72.

28. Allison ME, Hodgson HJ. Regulation of peripheral blood Bcell IgA production in alcoholic cirrhosis. J Clin Lab Immunol 1989; 30:127-30.

29. Mestecky J, Russel MW. IgA subclasses. Monogr Allergy 1986; 19:277-301.

30. Tarkowsji A, Lue C, Moldoveanu Z, Kiyono H, Mc Ghee JR, Mestecky J. Immunization of humans with polysaccharide vaccines induces systemic predominantly polymeric IgA2-subclass antibody response. J Immunol 1990; 144:3770-8.

31. Guillemin A, Kapel N, Meillet D, Magne D, Gobert JG. IgA fecal output in patients with liver cirrhosis. Act Pharm Biol Clin 1995; 8:432-5.

\section{Received October 15, 1996/February 5, 1997}

Corresponding author: Prof. Dominique Meillet, Laboratoire de Parasitologie - Mycologie, Faculté de Médecine et Pharmacie, 2, Place Saint-Jacques, F-25030 Besançon Cedex, France 
